\title{
Exploring the Role of Awareness in the CSR-CFP Relationship
}

\author{
Sebastien Vendette ${ }^{1}$ \\ ${ }^{1}$ Central Michigan University, Mount Pleasant, USA \\ Correspondence: Sebastien Vendette, Central Michigan University, Mount Pleasant, MI 48859, USA.
}

Received: October 5, 2021

Accepted: November 2, $2021 \quad$ Online Published: November 22, 2021

doi:10.5430/jms.v12n4p11

URL: https://doi.org/10.5430/jms.v12n4p11

\begin{abstract}
After more than seven decades and thousands of scholarly works on the topic, the question of whether corporate social responsibility (CSR) positively impacts a firm's performance has yet to find consensus. To date, extant research has found evidence of a positive, negative, and, in some cases, no relationship between CSR and firm performance. This paper tackles one of the possible reasons why the literature has experienced incongruent results. Specifically, this paper explores the role of CSR on firm performance when the assumption of stakeholder awareness is met. The results show that firms did experience an increase in firm performance once they made their stakeholders aware of their CSR activities. The role of awareness has major implications for research as it opens a brand-new path of investigation that focuses on the signal firms use, such as CSR reports, to make stakeholders aware of their activities.
\end{abstract}

Keywords: corporate social responsibility, stakeholder awareness, corporate financial performance

\section{Introduction}

The idea that businesses have some sort of moral obligation to societies beyond that of making pure profit for the shareholders is not new. In fact, it is even possible to find evidence of the business community's concern for social issues for centuries, starting with Plato's REPUBLIC notion which proposed that rulers owe citizens more than, simply, survival (Marks \& Miller, 2010). No one will argue against the fact that corporate social responsibility (hereafter, CSR) has a long and debated history. Over the past seven decades, the concept of CSR has continued to gain momentum and grow in importance and significance in both academia and in the practitioner communities.

While the quest for the business case of CSR has been developing, it remains, to this day, a fiercely debated topic (Margolis \& Walsh, 2007; Carroll \& Shabana, 2010). Recently, the search for the business case for CSR has accelerated and has developed into the establishment of the business justification and rationale for the implementation of CSR initiatives. That is, the specific benefits CSR brings to organizations in an economic and financial sense. To make the business case for CSR, research resolved around the question of whether organizations could perform financially as well as, or better by addressing both their core business strategies and operations and their responsibilities to the broader society (Kurucz, Colbert, \& Wheeler, 2008).

The answer to whether or not CSR improves the bottom line is extremely important to the various stakeholders of any given organization. And, given the pressure faced by organizations to engage in CSR, it is not surprising that a multitude of different business cases for CSR have been developed over the years. In fact, there are a myriad of accepted approaches to the business case that focus on the empirical research linking CSR with CFP and identifying the multiple benefits to different stakeholder groups that directly or indirectly benefit from the organizations' bottom lines. However, there is no single business case for CSR, no 'golden' rule or guideline for how CSR increases the bottom line. What we know, though, is that good deeds earn good chits and for organizations CSR, in practice, is now considered an integral strategic function of the firm. What is puzzling though, is why some firms earn positive financial benefits from their CSR activities while others do not. This particular question is at the heart of this paper. Specifically, this paper explores the role of stakeholder awareness as a catalyst for firms to earn positive financial returns from CSR activities. Afterall, if stakeholders are not made aware of a firm's good chits, it is unlikely that the benefits from engaging in CSR will come to fruition.

\section{The Case for and Against CSR}

Ever since the debate over CSR began over seven decades ago, supporters and detractors have been articulating the arguments for and against the idea of CSR. The case against the concept of CSR typically begins with the classical 
economic argument which views organizations as possessing one responsibility, that is to maximize the profits of its owners or shareholders. A second objection to CSR has been that businesses are not equipped to handle social activities. This position holds that managers are oriented towards finance and operations and do not have the necessary expertise, to make socially oriented decisions (Davis 1973). A third objection to CSR is that it is extremely difficult to integrate and embed CSR in the vision and activities at the core of corporate practices (Porter \& Kramer, 2006; Pruzan, 2001). The objection here is that to adopt CSR would put business into fields of endeavor that are unrelated to their business strategy (Hayek 1969, Pruzan, 2001). A fourth argument against CSR is that business already possess enough power as it is, and there are no reasons to give them the chance to wield additional power (i.e., social power; Davis 1973). A fifth argument is that, by pursuing CSR, organizations make themselves less competitive globally. It should be noted that the arguments presented here were introduced decades ago, though some researchers still hold them, and that the oppositions to the concept of CSR applied when the idea was once more narrowly conceived.

Arguments in favor of CSR typically begin with the belief that it is in business's long-term self-interest - enlightened self-interest - to be socially responsible. This view holds that, if business is to have a healthy climate in which to function in the future, it must take actions now that will ensure its long-term viability. A second argument in favor of CSR is that it will ward off government regulations. This is a very practical reason, and it is based on the idea that future government interventions can be forestalled to the extent that organizational polices can fulfill society's expectations with self-disciplined standards and expectations. Two additional arguments in favor of CSR include "business has the resources" and "let business try" (Davis, 1973). These two views maintain that, because organizations may possess a reservoir of management talent, functional expertise and capital, and because so many others have tried and failed to solve social problems, organizations should be given the chance (Davis 1973). Another justification for CSR holds that pro-acting is better than reacting. This basically means that pro-acting (anticipating, planning and initiating) is more practical and less costly than simply reacting to social problems once they have surfaced (Carroll \& Buchholtz, 2009; Torugsa, O'Donohue \& Hecker, 2013). Finally, it has been argued that business should engage in CSR because the public strongly supports it. Today, the public believes that, in addition to its pursuits of profits, business should be responsible to their workers, communities and other stakeholders, even if making things better for them requires companies to sacrifice some profits (Bernstein, 2000; Reinhardt, Stavins, \& Vietor, 2008). While organizations sacrifice some of their profits initially, the increased reputation gained from the CSR initiatives can have a significant effect on firm performance and allow them to achieve greater financial outcomes in the long-run outcome (Bernstein, 2000; Tsoutsoura, 2004). Many of these arguments for and against CSR have been around for decades. They certainly present the legitimate perspective that there are, indeed, two sides of the argument with respect to almost any concept.

\section{The Importance of Awareness for CSR}

While there are countless studies looking specifically at the CSR-CFP relationship, extant research has not been able to find consensus regarding the relationship. One possible reason why such incongruencies exists in early CSR research is due to CSR returns being contingent on customers' awareness of organizations' CSR endeavors (Bhattacharya \& Sen, 2003). In its quest into finding the 'true' impact of CSR on firm outcomes, researchers have mainly assumed the presence of the CSR awareness on the part of firms' relevant stakeholders. What is interesting, though, is that studies specifically investigating specific stakeholder groups indicated an overall lack of awareness of companies' CSR activities from both external stakeholders (e.g., consumers) and internal stakeholder (e.g., employees), which institutes a key stumbling block in organizations' quest to gain any strategic benefits from CSR activities (Bhattacharya, Sen, \& Korschun, 2008; Du, Bhattacharya, \& Sen, 2007; Sen, Bhattacharya, \& Korschun, 2006). Based on this finding, it seems likely that the benefits from CSR activities is contingent on organizations making stakeholders aware of their CSR through various signals (Kemper, Schilke, Reimann, Wang, \& Brettel, 2013). One way organization can signal their CSR initiatives, and by proxy increasing stakeholder awareness, is through the release of CSR reports (Author, 2021). By reporting their CSR activities through the use of CSR reports, firms are, in essence, building their legitimacy regarding their commitment to the CSR activities signaled (Chijoke-Mgbame, Mgbame, Akintoye \& Ohalehi, 2019). This legitimacy is considered to be key for organizations in their quest to gain a strategic advantage from their CSR activities. In fact, research suggests that firms who are seen as engaging in more legitimate CSR experience greater financial performance (Farache \& Perks, 2010). Therefore, signaling firms' CSR activities through the release of CSR reports appears to be a key factor in why some organizations experience financial benefits while others do not. Based on the aforementioned logic:

Research Question 1: Does making stakeholders aware of a firm's CSR activities impact the relationship between CSR and firm performance. 


\section{Methodology}

\subsection{Participants}

Data were collected from publicly owned organizations featured in the Russell 1000 database. Organizations were identified from CSRwire's archival database and Fortune magazine's Best Corporate Citizen list. The organizations were from a myriad of industries minimizing the likelihood of over representation from any specific industry. These organizations were targeted because of their commitment to CSR initiatives and in an attempt to gather archival information regarding the various decision makers in those organizations.

\subsection{Procedure}

Organizations were selected from CSRwire's newsletter archive. CSRwire is a third-party non-profit organization which keeps tracks of, and archives, news regarding organizations' CSR initiatives. Data were collected based on the newsletter from CSRwire's archive during the year 2000. A random sample was collected and after removing organizations that did not report financial information, the total sample totaled 77 organizations. Because stakeholders, in this case customers, must be aware of an organization's CSR initiative in order to find any significant relationship between CSR and firm performance (Bhattacharya \& Sen, 2003), organizations were selected based on whether they advertised any CSR initiatives to the public starting at year 2000. The year 2000 is used as a proxy for awareness because of the rapid growth of the internet's popularity and web-based reporting frequency. Additionally, because of the scarcity in the numbers of newsletter available prior to 2000 on the web, I believe it is appropriate to distinguish the year 2000 as an arbitrary cut-off to establish stakeholder awareness.

\section{Results}

The research question posited that the implementation of CSR initiatives would significantly affect firm performance when stakeholders are made aware of organizations' initiatives. To test this hypothesis, a paired-sample t-test was used where group 1 referred to the 3-year growth average pre-CSR implementation and group 2 represented the 3 -year growth average post CSR implementation. The analysis revealed a significant difference between the pre-CSR implementation $(\mathrm{M}=-.01, \mathrm{SD}=2.12)$ and post $\mathrm{CSR}$ implementation $(\mathrm{M}=1.04, \mathrm{SD}=2.03)$ group; $\mathrm{t}(74)=-3.34, \mathrm{p}$ $<.001 ; d=-.48$. The results suggest the implementation of CSR initiatives had a positive influence on firm performance when the assumption of awareness had been met. Table 1 reports the results of the analysis.

Table 1. Results of t-test and Descriptive Statistics for CFP pre and post CSR Implementation

\begin{tabular}{|c|c|c|c|c|c|c|c|c|c|}
\hline \multirow[b]{2}{*}{ Outcome } & \multicolumn{2}{|c|}{$\begin{array}{c}\text { Pre-CSR } \\
\text { Implementation }\end{array}$} & \multicolumn{2}{|c|}{$\begin{array}{c}\text { Post CSR } \\
\text { Implementation }\end{array}$} & \multirow[b]{2}{*}{$\mathrm{n}$} & \multirow{2}{*}{$\begin{array}{l}95 \% \text { CI for } \\
\text { Mean } \\
\text { Difference }\end{array}$} & \multirow[b]{2}{*}{$\mathrm{r}$} & \multirow[b]{2}{*}{$\mathrm{t}$} & \multirow[b]{2}{*}{$\mathrm{df}$} \\
\hline & M & SD & M & SD & & & & & \\
\hline CFP & .002 & 2.09 & .99 & 2.02 & 77 & $-1.6,-3.22$ & .14 & -3.22 & 76 \\
\hline
\end{tabular}

\section{Implications and Conclusion}

The purpose of this paper was to investigate the role of CSR activities on performance measures (CFP) when the assumption of stakeholders' awareness of organizations' CSR initiatives is met. According to the results of this study, firms that signaled their CSR activities through the use of CSR reports, making stakeholders aware of such firms' CSR initiatives, experienced increased firm performance. This is an important finding that holds both practical and scholarly significance.

Taking into consideration the role of awareness, several important questions need to be taking into account. First, once the assumption of stakeholder awareness is met, the next logical step deals with how stakeholders perceive the signals from CSR reports. Mainly, there are two ways stakeholders can view firms' CSR activities. Stakeholders may see firms engaging in CSR for intrinsic or societal purposes, or for self-serving purposes (Groza, Pronschinske \& Walker, 2011). This distinction is important because stakeholders' attribution of firms' intention plays an important role in generating positive assessments of firms. While firms often engage in CSR activities as a means to earn positive financial returns or to protect themselves against negative firm actions (Hersel, Helmuth, Zorn, Shropshire \& Ridge, 2019), stakeholders who perceive firms as engaging in CSR authentically (i.e., for societal purposes), are 
more likely to reward the firm for their 'good deeds' (Kim, Nurunnabi, Kim \& Kim, 2018). For example, firms that are perceived as acting authentically are more likely to been seen as credible resulting in increased positive attitudes towards the firm resulting in increased purchasing intentions (Afzali \& Kim, 2021).

A tangential, yet important, line of questioning concerns the commitment of firms toward their CSR activities. In line with the prior argument, when firms signal their CSR activities to stakeholders, they, in essence, become accountable (Author, 2021). An important line of investigation should focus on this accountability, specifically looking at the commitment firms possess in achieving the CSR goals signaled to stakeholders. The commitment towards achieving CSR goals can serve as a proxy for followers when assessing whether they are engaging in CSR for authentic or inauthentic purposes. When firms are perceived as commitment towards achieving their CSR goals, stakeholders may attribute authenticity to firm.

A final line of inquiry deals with the signal itself. Whereas this paper identified that making stakeholders aware of firms' CSR is crucial for them to earn positive financial reward from their CSR activities, it did not deal with the sender of the signal itself (Connelly, Certo, Ireland, \& Reutzel, 2011). This is because when looking at the signal of CSR, stakeholders are not only interpreting the content of the signal but also make sense of the signaler itself to determine the validity of the signal. Looking at the signaler opens an entirely new line of inquiry into the potential role of executives in influencing stakeholder attributions of CSR. Signals coming from CEOs are likely to offer stakeholders exclusive insights that may impact stakeholder attribution of CSR intent (Ogunfowora, Stackhouse \& Oh, 2018). While CEOs are key signal-sending actors and impact firms' propensity and motivation to engage in CSR (Manner 2010; Oh, Chang \& Cheng, 2016; Waldman, Siegel \& Javidan, 2006), yet little is known about the impact CEOs may have on shaping outside stakeholder attributions of CSR intent.

The result of this exploratory study indicated that firms experience increased levels of performance when stakeholders were made aware of their CSR activities. Taken this assumption a step further opens up a new line of inquiry for future scholars as they embark on finding the 'true' relationship between CSR and CFP. As organizations continue to experience pressure to engage in and promote their CSR activities, the hope is that this paper will spur future research that considers what can influence stakeholders' CSR attributions.

\section{References}

Afzali, H., \& Kim, S. S. (2021). Consumers' Responses to Corporate Social Responsibility: The Mediating Role of CSR Authenticity. Sustainability, 13(4), 2224. https://doi.org/10.3390/su13042224

Bernstein, A. (2000). Too much corporate power. Business Week, 11 September, p. 149.

Bhattacharya, C. B., \& Sen, S. (2003). Consumer-company identification: A framework for understanding consumers' relationships with companies. Journal of Marketing, 67(2), 76-88. https://doi.org/10.1509/jmkg.67.2.76.18609

Bhattacharya, C. B., Sen, S., \& Korschun, D. (2008). Using corporate social responsibility to win the war for talent. Sloan Management Review, 49, 37-44.

Carroll, A. B., \& Buchholtz, A. K. (2009). Business and Society: Ethics and Stakeholder Management (7th ed.). Mason, OH: South-Western Cengage Learning.

Carroll, A. B., \& Shabana, K. M. (2010). The business case for corporate social responsibility: a review of concepts, research and practice. International Journal of Management Reviews, 12(1), 85-105. https://doi.org/10.1111/j.1468-2370.2009.00275.x

Chijoke-Mgbame, A. M., Mgbame, O. C., Akintoye, S., \& Ohalehi, P. (2019). The role of corporate governance on CSR disclosure and firm performance in a voluntary environment. Corporate Governance: The International Journal of Business in Society, 20(2), 294-306. https://doi.org/10.1108/CG-06-2019-0184

Connelly, B. L., Certo, S. T., Ireland, R. D., \& Reutzel, C. R. (2011). Signaling theory: A review and assessment. Journal of Management, 37(1), 39-67. https://doi.org/10.1177/0149206310388419

Davis, K. (1973). The case for and against business assumption of social responsibilities. Academy of Management Journal, 16(2), 312-322. https://doi.org/10.2307/255331 
Du, S., Bhattacharya, C. B., \& Sen, S. (2007). Reaping relationship rewards from corporate social responsibility: the role of competitive positioning. International Journal of Research in Marketing, 24, 224-241. https://doi.org/10.1016/j.ijresmar.2007.01.001

Farache, F., \& Perks, K. J. (2010). CSR advertisements: a legitimacy tool?. Corporate Communications: An International Journal, 15(3), 235-248. https://doi.org/10.1108/13563281011068104

Groza, M. D., Pronschinske, M. R., \& Walker, M. (2011). Perceived organizational motives and consumer responses to proactive and reactive CSR. Journal of Business Ethics, 102(4), 639-652. https://doi.org/10.1007/s10551-011-0834-9

Hayek, F. A. (1969). The corporation in a democratic society: in whose interest ought it and will it be run?. In H. Ansoff (Ed.), Business Strategy (p. 225). Harmondsworth: Penguin Books.

Hersel, M. C., Helmuth, C. A., Zorn, M. L., Shropshire, C., \& Ridge, J. W. (2019). The corrective actions organizations pursue following misconduct: A review and research agenda. Academy of Management Annals, 13(2), 547-585. https://doi.org/10.5465/annals.2017.0090

Kemper, J., Schilke, O., Reimann, M., Wang, X., \& Brettel, M. (2013). Competition-motivated corporate social responsibility. Journal of Business Research, 66(10), 1954-1963. https://doi.org/10.1016/j.jbusres.2013.02.018

Kim, B. J., Nurunnabi, M., Kim, T. H., \& Kim, T. (2018). Doing good is not enough, you should have been authentic: Organizational identification, authentic leadership and CSR. Sustainability, 10(6), 2026. https://doi.org/10.3390/su10062026

Kurucz, E., Colbert, B., \& Wheeler, D. (2008). The business case for corporate social responsibility. In A. Crane, A. McWilliams, D. Matten, J. Moon, \& D. Siegel (Eds.), The Oxford Handbook of Corporate Social Responsibility (pp. 83-112). Oxford: Oxford University Press. https://doi.org/10.1093/oxfordhb/9780199211593.003.0004

Manner, M. (2010). The impact of CEO characteristics on corporate social performance. Journal of Business Ethics, 93, 53-72. https://doi.org/10.1007/s10551-010-0626-7

Margolis, J. D., Elfenbein, H. A., \& Walsh, J. P. (2007). Does it pay to be good? A meta-analysis and redirection of research on the relationship between corporate social and financial performance. Ann Arbor, 1001, 48109-1234.

Marks, C., \& Miller, P. S. (2010). Plato, The Prince, and Corporate Virtue: Philosophical Approaches to Corporate Social Responsibility. USFL Rev., 45, 1.

Ogunfowora, B., Stackhouse, M., \& Oh, W. Y. (2018). Media depictions of CEO ethics and stakeholder support of CSR initiatives: The mediating roles of CSR motive attributions and cynicism. Journal of Business Ethics, 150(2), 525-540. https://doi.org/10.1007/s10551-016-3173-Z

Oh, W. Y., Chang, Y. K., \& Cheng, Z. (2016). When CEO career horizon problems matter for corporate social responsibility: The moderating roles of industry-level discretion and blockholder ownership. Journal of Business Ethics, 133, 279-291. https://doi.org/10.1007/s10551-014-2397-z

Porter, M. E., \& Kramer, M. R. (2006). Strategy and Society: The Link Between Competitive Advantage and Corporate Social Responsibility. Harvard Business Review, 84(12), 78-92.

Pruzan, P. (2001). The Question of Organizational Consciousness: Can Organizations have Values, Virtues and Visions?. Journal of Business Ethics, 29(3), 271-284. https://doi.org/10.1023/A:1026577604845

Reinhardt, F. L., Stavins, R. N., \& Vietor, R. H. (2008). Corporate social responsibility through an economic lens. Review of Environmental Economics and Policy, 2(2), 219-239. https://doi.org/10.1093/reep/ren008

Sen, S., Bhattacharya, C. B., \& Korschun, D. (2006). The role of corporate social responsibility in strengthening multiple stakeholder relationships: A field experiment. Journal of the Academy of Marketing Science, 34(2), 158-166. https://doi.org/10.1177/0092070305284978

Torugsa, N. A., O’Donohue, W., \& Hecker, R. (2013). Proactive CSR: An empirical analysis of the role of its economic, social and environmental dimensions on the association between capabilities and performance. Journal of Business Ethics, 115(2), 383-402. https://doi.org/10.1007/s10551-012-1405-4 
Tsoutsoura, M. (2004). Corporate social responsibility and financial performance. Working Paper Series (7), Center for Responsible Business, University of California, Berkeley, CA.

Vendette, S. (2021). The Effect of Authentic Corporate Social Responsibility (CSR) Intent and Substantiveness on Firm Performance. Academy of Strategic Management Journal, 20(1), 1-23.

Waldman, D. A., Siegel, D. S., \& Javidan, M. (2006). Components of CEO transformational leadership and corporate social responsibility. Journal of Management Studies, 43, $1703-1725$. https://doi.org/10.1111/j.1467-6486.2006.00642.x

\section{Copyrights}

Copyright for this article is retained by the author(s), with first publication rights granted to the journal.

This is an open-access article distributed under the terms and conditions of the Creative Commons Attribution license (http://creativecommons.org/licenses/by/4.0/). 